Economics Development Analysis Journal 6 (4) (2017)

\title{
Analisis Rantai Nilai Komoditas Cabai Merah di Agrowisata Desa Candi Kecamatan Bandungan Kabupaten Semarang
}

\author{
Dhamon Oridilla $\mathbf{B}^{\bowtie}$
}

Jurusan Ekonomi Pembangunan, Fakultas Ekonomi, Universitas Negeri Semarang

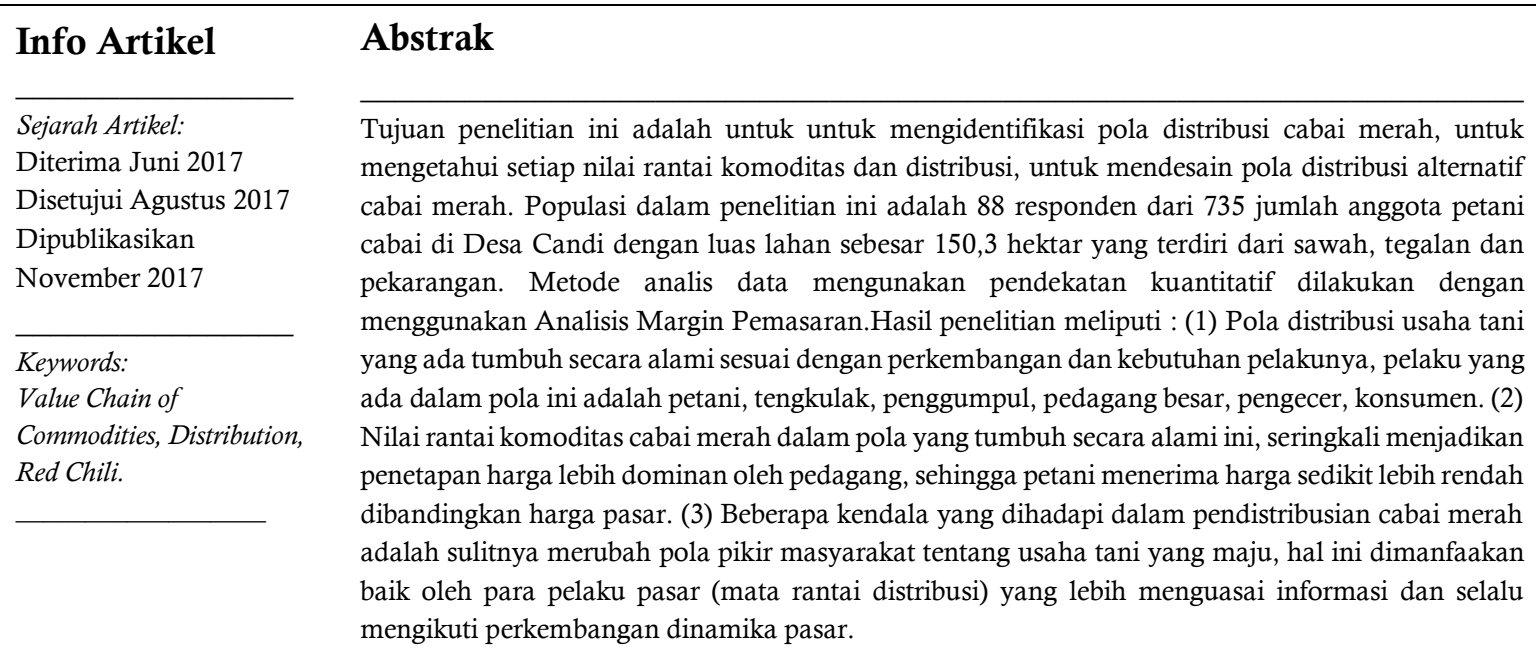

\begin{abstract}
The purpose of this research is to identify the distribution pattern of red pepper, to know each value of commodity chains and distribution, to design alternative distribution pattern of red pepper.Population in this research is 88 respondents from 735 of member of chilli farmer in Desa Candi with total area of 150,3 hectare consisting of rice field, moor and yard. Methods of data analyst using quantitative approach is done by using Margin Marketing Analysis. The results include: (1) The pattern of distribution of existing farming business grows naturally in accordance with the developments and needs of the perpetrators, the actors in this pattern are farmers, wholesalers, collectors, wholesalers, retailers, consumers. (2) The value of the red chili commodity chain in this naturally grown pattern often makes pricing more dominant by traders, so farmers receive prices slightly lower than market prices. (3) Some obstacles faced in distributing red peppers are the difficulty of changing the mindset of the community about advanced farming, this is best utilized by market participants (chain of distribution) who are more informed and always keep abreast of market dynamics.
\end{abstract}

(C) 2017 Universitas Negeri Semarang

E-mail: damonboys@ymail.com 


\section{PENDAHULUAN}

Indonesia merupakan negara beriklim tropis dengan kondisi daratannya yang dikelilingi pegunungan dan struktur tanah yang subur serta kaya akan sumber daya alam, sehingga banyak dimanfaatkan oleh penduduk sebagai lahan pertanian. Karakteristik Indonesia sebagai negara agraris menyiratkan bahwa sektor pertanian memiliki peranan penting dalam pembangunan perekonomian nasional. Pembangunan pertanian yang berkelanjutan diarahkan untuk meningkatkan produksi pertanian guna memenuhi kebutuhan pangan dan kebutuhan industri dalam negeri, meningkatkan ekspor, meningkatkan pendapatan petani, memperluas kesempatan kerja, serta mendorong pemerataan kesempatan berusaha (Kuncoro, 2010).

Pertanian dalam arti sempit diartikan sebagai pertanian rakyat yaitu usaha pertanian keluarga dimana diproduksi bahan makanan utama seperti, beras, palawija (jagung, kacangkacangan dan ubi-ubian) dan tanaman tanaman hortikultura yaitu sayur-sayuran dan buahbuahan. Usaha tani ini pada umumnya diusahakan dengan tujuan utama untuk memenuhi kebutuhan kehidupan (subsistensi) petani dan keluarganya. Secara ekonomis dapat dikatakan bahwa hasilnya sebagian besar untuk memenuhi konsumsi keluarga dan faktor faktor produksi atau modal yang dipergunakan sebagian besar berasal dari usaha tani itu sendiri (Mubyarto.1989: 17).

Salah satu komoditas hortikultura yang memiliki nilai ekonomi penting di Indonesia adalah cabai merah. Dimusim hujan, harga cabai cenderung melambung, dengan pengelolaan tanaman secara tradisionil sulit diharapkan hasilnya yang optimal, sebab pada musim hujan serangan hama dan penyakit sangat hebat, Cabai ternyata mampu sebagai penyebab tingginya laju inflasi nasional tersebut, mununjukkan bahwa cabai benar-benar merupakan komoditas sayuran yang sangat dibutuhkan dalam kehidupan seharihari. Hasil panen tertinggi terjadi pada tahun 2015 sebesar 87,03 kwintal, pada tahun 2011 sebesar 80,23 kwintal, akan tetapi pada tahun
2014 mengalami penurunan yang cukup drastis bahkan ditahun 2009 sendiri penurunannya mencapai angka 35,82 .

Selain untuk memenuhi kebutuhan rumah tangga, permintaan akan cabai oleh industri dari hari ke hari terus meningkat, seiring dengan makin maraknya industri pengolahan bahan makanan menggunakan cabai sebagai bahan baku utamanya, misalkan sambal, saus, dan mie instan. Cabai merupakan salah satu komoditas hortikultura yang memiliki nilai ekonomi penting di Indonesia. Dari tahun 2012-2015 harga cabai merah mengalami kenaikan terusmenerus. Tingginya harga jual dan beli cabai merah dibeberapa tahun terakhir yang sampai pada kisaran Rp 50.000 - Rp 60.000 tahun 2015, hal ini menyebabkan tanaman tersebut masuk dalam agenda pembicaraan nasional.

Kabupaten Semarang tepatnya di Desa Candi Kecamatan Bandungan merupakan salah satu kecamatan agrowisata pemasok cabai untuk Kabupaten Semarang dan sekitarnya memiliki agroklimat yang sesuai untuk pengembangan berbagai macam komoditi pertanian didukung peluang pasar yang cukup luas Sehingga sangat cocok untuk pengembangan usaha pertanian.

Pengembangan pertanian bertujuan untuk kesejahteraan petani dan keluarganya dalam berusaha tani dengan melakukan agribisnis pertanian sayuran yang tangguh dan profesional serta berwawasan lingkungan, kawasan ini sangat cocok ditanami sayur-sayuran karena memiliki keunggulan komparatif. Sistem tata niaga yang efisien dan efektif dapat mendorong kelancaran arus barang dan jasa di pasar dengan harga yang layak bagi produsen dan terjangkau oleh daya beli konsumen. Kelancaran arus barang dan jasa serta meluasnya pasar untuk produk dalam negri akan memperluas kesempatan kerja dan meningkatkan kesejahteraan masyarakat.

Pemasaran komoditas pertanian selama ini mempunyai mata rantai yang sangat panjang, mulai dari petani produsen, pedagang pengumpul, pedagang besar, pedagang pengecer hingga ke konsumen, sehingga mengakibatkan kecilnya keuntungan yang diperoleh petani 
secara umum sistem pemasaran holtikultura dapat dikemukakan pada (Gambar 1.3). Ukuran dilihat dari kesuksesan mata rantai supply adalah seberapa baik aktivitas mengkoordinasikan seluruh rantai supply untuk menciptakan nilai bagi konsumen, sekaligus meningkatkan profitabilitas setiap unit (Mudda, 2016). Peran mata rantai supply yaitu mengatur persediaan dari pasokan bahan baku pokok untuk produk akhir .

Pola pemasaran konvensional yang dilakukan petani menyebabkan tingkat harga yang diterima oleh petani pada umumnya relatif lebih kecil dibandingkan dengan harga yang diterima oleh pedagang. Keuntungan yang diterima oleh petani dari kegiatan usahataninya juga relatif kecil, sementara konsumen harus membayar lebih mahal dari harga yang selayaknya ditawarkan, hal ini sebagai akibat dari terjadinya biaya pemasaran yang tinggi dari petani hingga sampai kepada konsumen akhir, sebagian besar petani telah terikat modal dan saprodi kepada pedagang atau pemilik modal. Dengan demikian pemasaran hasil lansung ditujukan kepada para pedagang atau pemilik modal tersebut. Salah satu upaya yang dapat dilakukan untuk meningkatkan efisiensi pemasaran dan meningkatkan nilai tambah petani dan produk agribisnis adalah dengan mengembangkan infrastruktur pemasaran antara lain dengan mengembangkan Sub Terminal Agribisnis (STA). Pengelolaan STA tidak hanya sebagai tempat pelelangan produk agribisnis tetapi juga sebagai tempat pelayanan berbagai kepentingan pelaku agribisnis (petani, pengolah dan pedagang).

Selain itu, letak keberadaan STA menimbulkan tambahan biaya angkut yang harus ditanggung oleh para petani dari lokasi produksi ke lokasi STA. Para pedagang besar, sampai saat ini bisa langsung datang ke petani atau pedagang desa untuk memperoleh cabai tanpa harus melalui pasar lelang yang ada, dengan patokan harga yang berlaku atau disepakati. Dengan aadanya pembelian sistem ijon, posisi tawar menawar petani sangat dilemahkan. Begitu pula di tingkat pedagang pengumpul, sebagian besar pedagang atau

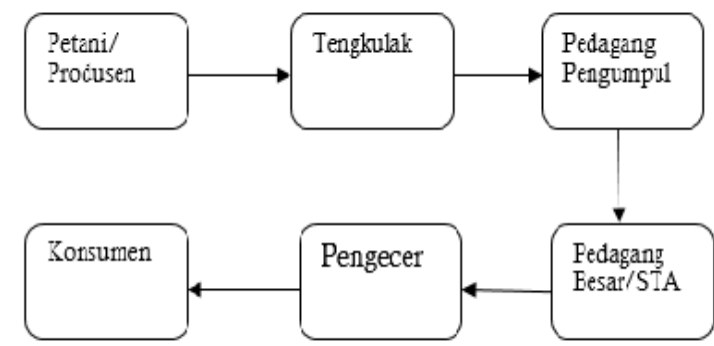

bandar sudah lama terjalin saluran tataniaga dan hubungan dagang sampai ke tempat pemasaran ahkir. Permasalahan tersebut akan menyulitkan keberadaan pasar lelang untuk menjalankan fungsinya sebagai mediator antara petani dengan para konsumen, pedagang pengumpul serta bandar.

Gambar 1. Rantai Nilai Pemasaran Holtikultura Sumber: Dinas Pertanian Provinsi Jawa Tengah Tahun 2015

Selain beberapa faktor tersebut peran lembaga yang ada dalam sektor pertanian dan pedesaan juga sangat penting dalam menunjang keberhasilan, walaupun banyak masyarakat yang kurang aktif yang menyebabkan lembaga mati, namun banyak juga kelompok baru yang sesuai dengan iklim pembangunan pertanian dalam pedesaan, perkembangan lembaga pertanian terutama kelompok tani sangat penting dalam pertanian dan pembangunan pertanian yaitu administrasi pemerintahan, pendidikan dan penyuluhan, kegiatan gotong royong dan lainlain faktor sosial budaya yang berpengaruh terhadap pembangunan sektor pertanian karena pada hakekatnya kelompok tani adalah organisasi yang memiliki fungsi sebagai media musyawarah petani. Untuk lebih jelas mengenai jumlah kelompok tani yang masih aktif di Desa Candi tahun 2015, dapat dilihat pada tabel 1.2 dibawah ini.

Tabel 1. Kelompok Tani Desa Candi Kecamatan Bandungan Th. 2015

Sumber data: kantor kepala Desa candi

$\begin{array}{cccc}\text { Dusun } & \text { Nama } & \text { Jumlah } & \text { Jumlah } \\ \text { Kelompok } & \begin{array}{c}\text { Anggota } \\ \text { tani }\end{array} & \text { Luas } \\ & & & \\ & & \end{array}$




\begin{tabular}{llll}
\hline & & & $\begin{array}{c}\text { Lahan } \\
\text { (ha) }\end{array}$ \\
\hline Tarukan & Agung Rejeki & 260 & 45 \\
Nglarangan & Arum Rejeki & 70 & 20,3 \\
Talun & Tani & 225 & 45 \\
& Manunggal & & \\
Ngipik & Subur Rejeki & 180 & 40 \\
\hline
\end{tabular}

Pada tabel diatas menunjukan jumlah kelompok tani di Agrowisata Desa Candi Kecematan Bandungan Kabupaten Semarang pada tahun 2015, terdapat 4 dusun yang merupakan kelompok tani yang menanam cabai merah. Kelompok tani yang yang juga menanam komoditas cabe merah pada Kecamatan ini adalah kelompok tani Arum Rejeki di dusun Nglarangan, kelompok tani Agung Rejeki di dusun Tarukan, kelompok tani subur rejeki di dusun Ngipik dan kelompok tani Tani Manunggal di dusun Talun dan kegiatan kelompok tani cabai di desa ini disamping menanam cabai mereka juga petani bunga hias.

\section{METODE PENELITIAN}

Pendekatan yang digunakan oleh peneliti adalah pendekatan kualitatif. Populasi yang digunakan adalah semua jumlah Kelompok petani cabai di Desa Candi dengan luas lahan sebesar 150,3 hektar yang terdiri dari sawah, tegalan dan pekarangan. Terdiri dari 4 kelompok tani dan 735 orang anggota kelompok tani yang merupakan petani pemilik sekaligus penggarap. Kelompok tani cabai pada Kecamatan ini adalah kelompok tani Arum Rejeki di dusun Nglarangan, kelompok tani Makmur Rejeki di dusun Tarukan, kelompok tani subur rejeki di dusun Ngipik dan kelompok Tani Manunggal di dusun Talun dan kegiatan kelompok tani cabai di desa ini disamping menanam cabai mereka juga petani bunga hias. Teknik pengambilan sampel dalam penelitian ini menggunakan teknik area proportional random sampling. Teknik ini adalah apabila populasi yang diambil sifatnya heterogen dan populasi tersebut diklasifikasikan lagi menjadi sub populasi. Area proportional random sampling yaitu teknik pengambilan sampel secara acak dari populasi berdasarkan wilayah dengan proporsi pengambilan secara seimbang.

Salah satu asumsi dasar pada analisis rantai nilai (value chain analysis) adalah pengembangan pasar yang bertujuan memberi dampak positif pada suatu tatanan kehidupan masyarakat dengan cara memberi pendapatan atau kepastian pekerjaan yang lebih baik melalui keikutsertaan mereka dalam mengembangkan pasar. Hal ini berarti mendorong terjadinya sinergi antara para petani atau produsen dengan wirausaha pengolahan pasca panen sehingga tanpa disadari mampu meningkatkan pendapatan masyarakat yang ada di dalam tata kelola rantai nilai tersebut. Dengan terintegrasinya sektor pertanian dengan sektor home industry masyarakat maka akan terbentuk suatu rantai nilai yang akan memberikan tambahan penghasilan serta menyerap tenaga kerja dengan kehadiran para pelaku (petani atau produsen utama, pengolah, pedagang, penyedia jasa) dalam rantai nilai tersebut.

Pada pendekatan kualitatif, data dianalisa dengan menggunakan model interaktif. Pada pendekatan kuantitatif dilakukan dengan menggunakan Analisis Margin Pemasaran dilengkapi dengan analisis diskripsi:

Analisis Margin Pemasaran, digunakan mengukur keuntungan masing-masing aktor yang terlibat dalam proses distribusi cabai merah

$\mathrm{MP} \quad=\mathrm{Pr}-\mathrm{Pf}$

Keterangan:

$\mathrm{MP}=$ margin pemasaran $(\mathrm{Rp} / \mathrm{kg})$;

$\mathrm{Pr}=$ harga konsumen $(\mathrm{Rp} / \mathrm{kg})$;

$\mathrm{Pf}=$ harga produsen $(\mathrm{Rp} / \mathrm{kg})$

Share harga yang diterima petani, merupakan prosentase keuntungan yang diterima petani

SPf $\quad=\mathrm{Pf} / \mathrm{Pr}$

Keterangan:

SPf = share harga ditingkat petani;

$\mathrm{Pf}=$ harga di tingkat petani;

$\operatorname{Pr}=$ harga di tingkat konsumen 


Share biaya pemasaran dan share
keuntungan
Sbi $=($ bi $/ \mathrm{Pr}) \times 100 \%$
Ski $=(\mathrm{ki} / \mathrm{Pr}) \times 100 \%$
Keterangan:
Sbi $=$ Share biaya pemasaran ke $\mathrm{i} ;$
$\mathrm{Ski}=$ Share keuntungan pemasaran ke $\mathrm{i} ;$
$\mathrm{bi}=$ biaya pemasaran;
$\mathrm{ki}=$ keuntungan pemasaran;
$\mathrm{Pr}=$ harga ditingkat konsumen.

Distribusi marjin pemasaran

$\mathrm{DM}=(\mathrm{Mi} / \mathrm{Mtot}) \times 100 \%$

Keterangan:

$\mathrm{DM}=$ Distribusi marjin;

$\mathrm{Mi}=$ Marjin pemasaran kelompok lembaga pemasaran;

M1 = Tengkulak

M2 = Pedagang Pengepul

M3 = Pedagang Besar

M4 $=$ Pengecer

$\mathrm{Mtot}=\mathrm{Mi}+\mathrm{M} 2+\mathrm{M} 3+\mathrm{M} 4$

\section{HASIL DAN PEMBAHASAN}

Hasil penelitian dilapangan yang dikumpulkan peneliti hampir sebagian petani bergantung dalam memasarkan hasil pertaniannya kepada tengkulak. tersebut dapat digambarkan bentuk pola saluran pemasaran Cabai Merah Besar Besar di kabupaten Semarang. Pedagang besar memiliki jaringan pasar luas baik di pasar lokal Semarang, Jakarta dan Luar Jawa. Pedagang besar menjual cabai kepada pengecer. Pengecer merupaka rantai distribusi terahkir yang berhadapan langsung dengan konsumen rumah tangga.

Saluran pemasaran ini banyak dilakukan oleh petani cabai dimana petani menjual cabainya kepada tengkulak dan tengkulak langsung menjualnya kepada pengepul. Pengumpul inilah yang mendistribusikan cabai yang dihasilkan oleh petani di Desa Candi kepada pedagang besar yang ada di pasar-pasar.

Berdasarkan ketiga saluran pemasaran cabai yang ada di Desa candi dapat dilihat bahwa yang mempunyai peranan besar dalam mendistribusikan cabai ke tangan konsumen adalah pedagang besar, dimana pedagang besar ini biasanya didukung oleh permodalan yang cukup besar, sudah memiliki gudang dan sudah melakukan fungsi-fungsi pemasaran selain pembelian dan penjualan seperti sortasi dan pengepakan.

Dengan demikian pelu adanya sistem terkendali dalam pola distribusi, agar nilai rantai distribusi menurun dan harga menjadi rendah, sehinga petani dan konsumen tidak dirugikan, selain itu fungsi dan manfaat dari STA berjalan dengan baik sistem tersebut yaitu dengan cara pemangkasan saluran distribusi pemasaran yang terkendali dimana fungsi dari kelompok tani bisa digunakan, dengan memanfaatkan kelompok tani para tengkulak dan pengumpul tidak bisa mempermainkan harga jadi harga cabai bisa dikendalikan oleh para petani. Sehingga dengan mengunakan sistem terkendali bisa menghindari nilai rantai yang tinggi, petani tidak dirugikan dan konsumen mendapatkan harga yang rendah.

Analisis margin pemasaran ini bertujuan untuk melihat efisiensi pemasaran yang diindikasikan oleh besarnya keuntungan yang diterima oleh masing-masing pelaku pemasaran. Semakin tinggi porsi yang diterima produsen berarti semakin efisien sistem pemasaran tersebut. Besarnya keuntungan yang diterima oleh masing-masing pelaku pemasaran relative terhadap harga yang dibayar konsumen dan atau relatif terhadap biaya pemasaran terkait dengan peran yang dilakukan masing-masing lembaga pemasaran.

Pada penelitan tentang pemasaran Cabai Merah Besar di Desa Candi Kecamatan Bandungan Kabupaten Semarang. Adapun perhitungan margin pada tiap pola pemasaran dapat dilihat pada tebel 2 .

. Berdasarkan Tabel Margin Pemasaran, Margin Distribusi, dan Share Distribusi Cabai Merah Besar Pola I. terlihat bahwa margin pemasaran yang terjadi antara petani dan pedagang pengecer sangat besar yaitu $R p$ $22.600,00 / \mathrm{kg}$ Cabai. Hal ini dimungkinkan karena panjangnya saluran pemasaran yang terjadi. Pembagian keuntungan yang diterima masing-masing lembaga pemasaran cukup bervariasi, dimana bagian terbesar diterima oleh 
lembaga pemasaran terakhir, yaitu pedagang pengecer. Besaran margin tersebut didistribusikan untuk tengkulak dan pada keuntungan tengkulak serta pengepul pada biaya sebesar $6.63 \%$ dan pada keuntungan $11.06 \%$, untuk pedagang besar pada biaya $6.63 \%$ dan pada keuntungan $13.27 \%$ \& sedangkan untuk pengecer pada biaya sebesar $6.63 \%$ dan pada keuntungan tengkulak sebesar $17.69 \%$. Untuk share harga petani hanya menerima bagian sebesar $46.94 \%$.

Tabel 2. Margin Pemasaran, Margin Distribusi, dan

Pembagian Distribusi Cabai Merah Besar Pola I

\begin{tabular}{|c|c|c|c|c|c|}
\hline NO & KOMPONEN & $\begin{array}{l}\text { NILAI } \\
(\mathrm{Rp} / \mathrm{Kg})\end{array}$ & MARGIN & $\begin{array}{l}\text { DISTRIBUSI } \\
\text { MARGIN }\end{array}$ & $\begin{array}{l}\text { SHARE } \\
(\%)\end{array}$ \\
\hline \multirow[t]{3}{*}{1.} & $\begin{array}{l}\text { PETANI } \\
\text { Harga jual }\end{array}$ & 20.000 & & & 46.94 \\
\hline & TENGKULAK & & & & \\
\hline & Harga & 20.000 & & & \\
\hline \multirow{7}{*}{2.} & Bongkar muat & 1500 & & 6.63 & 3.52 \\
\hline & Transport & 1500 & & 6.63 & 3.52 \\
\hline & Keuntungan & 3000 & & 13.27 & 7.04 \\
\hline & Harga jual & 26.000 & 6.000 & & 61.03 \\
\hline & PENGEPUL & & & & \\
\hline & Harga & 26.000 & & & \\
\hline & Sortasi & 800 & & 3.53 & 1.87 \\
\hline \multirow[t]{7}{*}{3.} & Penyusutan & 500 & & 2.21 & 1.17 \\
\hline & Transport & 1500 & & 6.63 & 3.52 \\
\hline & Keuntungan & 2500 & & 11.06 & 5.86 \\
\hline & Harga jual & 31.300 & 5.300 & & 73.47 \\
\hline & PEDAGANG & & & & \\
\hline & BESAR & & & & \\
\hline & Harga & 31.300 & & & \\
\hline \multirow{7}{*}{4.} & Sortasi & 800 & & 3.53 & 1.87 \\
\hline & Penyusutan & 500 & & 2.21 & 1.17 \\
\hline & Pengemasan & 1500 & & 6.63 & 3.52 \\
\hline & Keuntungan & 3000 & & 13.27 & 7.04 \\
\hline & Harga jual & 37.100 & 5.800 & & 87.08 \\
\hline & PENGECER & & & & \\
\hline & Harga & 37.100 & & & \\
\hline \multirow[t]{4}{*}{5.} & Transport & 1500 & & 6.63 & 3.52 \\
\hline & Keuntungan & 4000 & & 17.69 & 9.38 \\
\hline & Harga jual & 42.600 & 5.500 & & 100.00 \\
\hline & Jumlah & & 22.600 & & \\
\hline
\end{tabular}

erdasarkan Tabel Margin Pemasaran, Margin Distribusi, dan Share Distribusi Cabai Merah Besar Pola II terlihat bahwa nilai margin pemasaran yang terjadi antara petani dan pedagang pengecer cukup besar yaitu $\mathrm{Rp}$ $16.600,00 / \mathrm{kg}$ Cabai.

Besarnya margin tersebut didistribusikan untuk pengepul pada biaya sebesar $9.03 \%$ dan pada keuntungan $15.06 \%$, untuk pedagang besar pada biaya $9.03 \%$ dan pada keuntungan sebesar $18.07 \%$ \& sedangkan untuk pengecer pada biaya sebesar $9.03 \%$ dan pada keuntungan sebesar $24.09 \%$. Untuk share harga petani hanya menerima bagian sebesar $57.54 \%$. 
Tabel 3. Margin Pemasaran, Margin Distribusi, dan

Share Distribusi Cabai Merah Besar Pola II

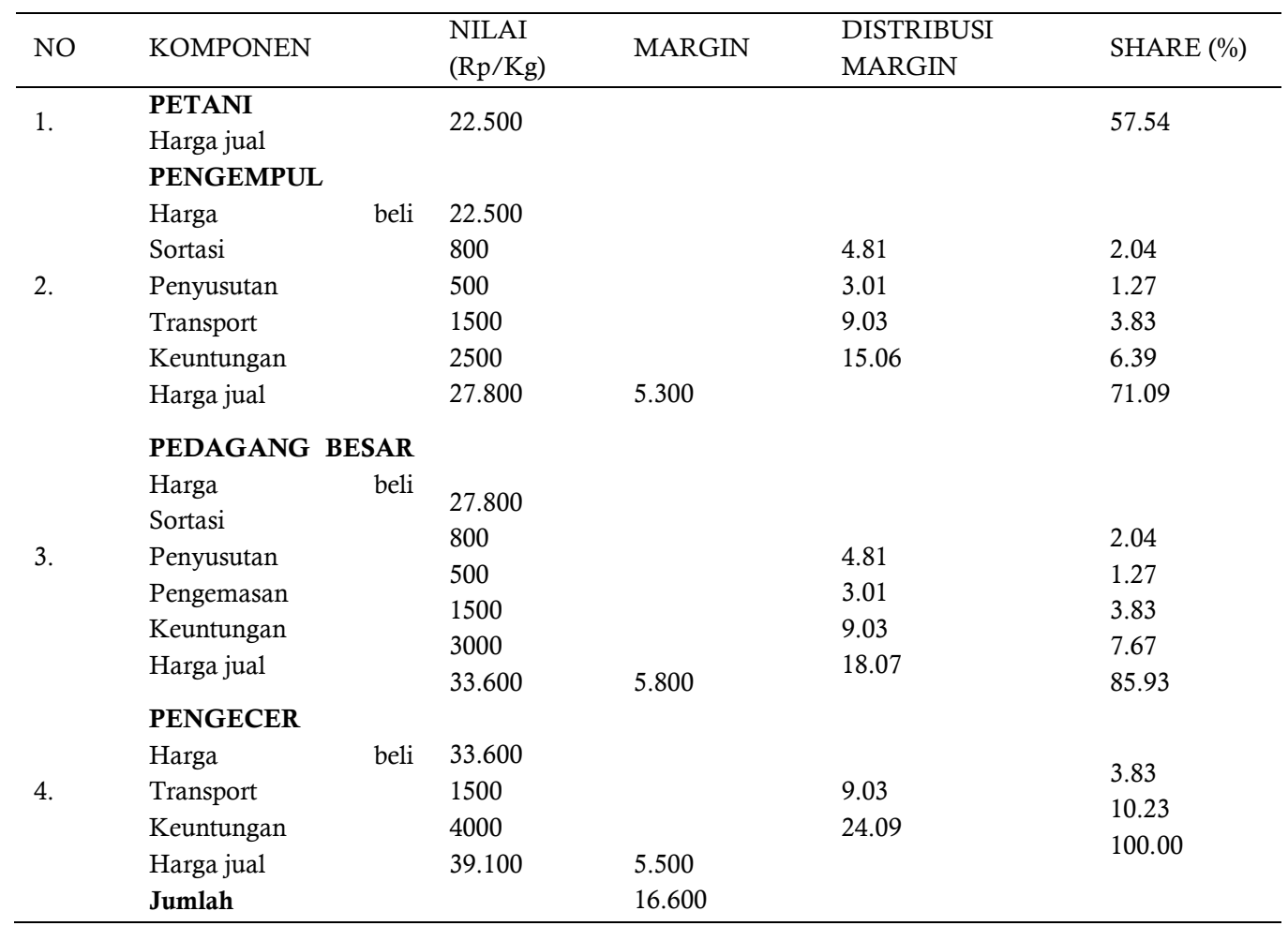

Sumber: Data diolah 2017

Tabel 4. Margin Pemasaran, Margin Distribusi, dan Share Distribusi Cabai Merah Besar Pola III

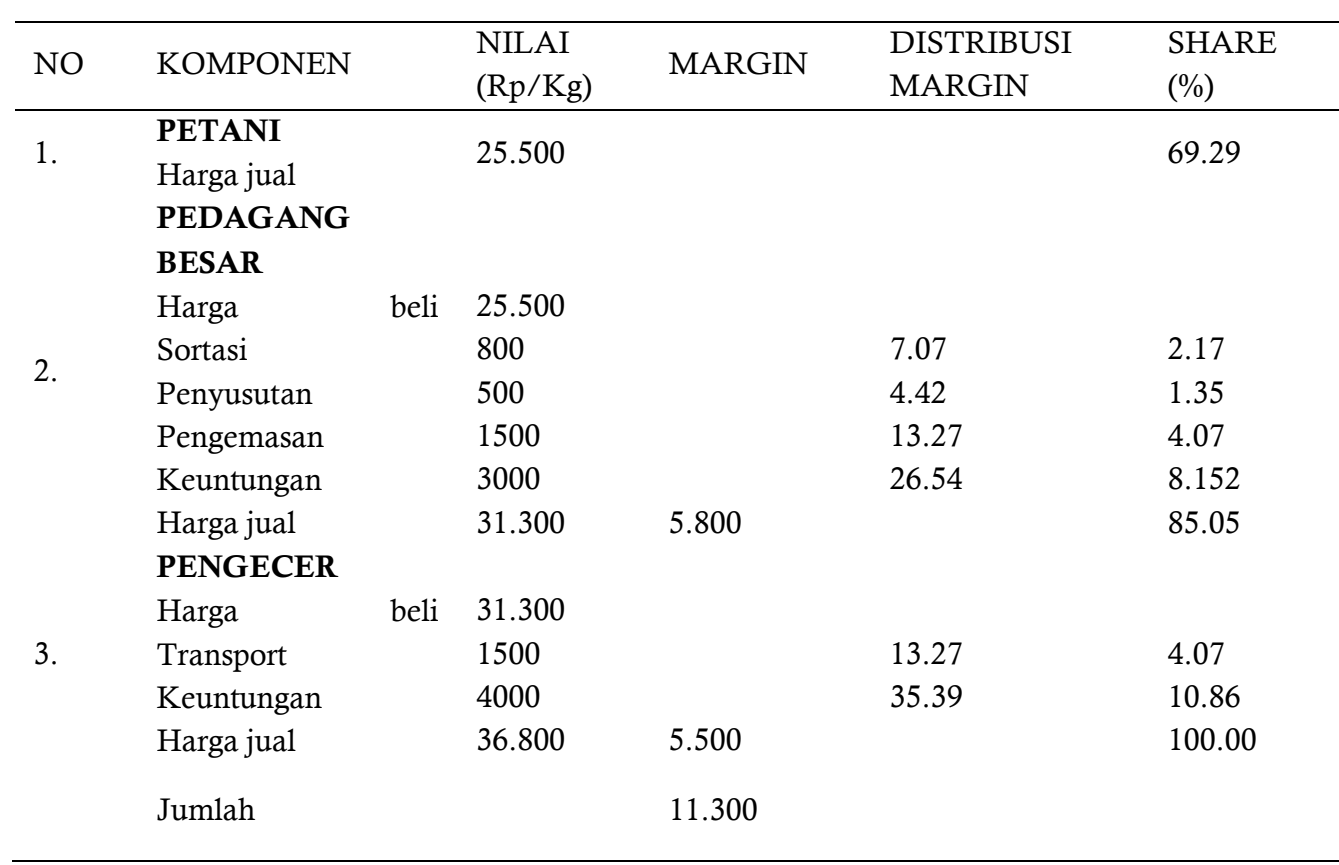


Sumber: Data diolah 2017

Margin pemasaran yang terjadi pada Tabel diatas Margin Pemasaran, Margin Distribusi, dan Share Distribusi Cabai Merah Besar Pola III antara petani dan pedagang pengecer sama besar pada pola III yaitu $\mathrm{Rp}$ $11.300,00 / \mathrm{kg}$ Cabai.

Besarnya margin tersebut didistribusikan untuk pedagang besar pada biaya $13.27 \%$ dan pada keuntungan $26.54 \%$ \& sedangkan untuk pengecer pada biaya sebesar $13.27 \%$ dan pada keuntungan pengecer sebesar $35.39 \%$. Untuk share harga petani hanya menerima bagian sebesar $69.29 \%$.

Komoditi agribisnis pada Cabai Merah Besar masih banyak ditentukan oleh peran pihak pelaku pemasaran di tingkat hilir seperti pedagang pengumpul dan pedagang besar (bandar), sehingga peran petani (produsen) dalam proses pemasaran hasil belum terlihat jelas, kecuali pada para petani dengan status ganda dan petani dengan skala usaha yang besar. Dengan keadaan seperti ini kapasitas petani dalam proses penentuan harga masih relatif kecil.

Panjangnya saluran distribusi Cabai Merah Besar ini ternyata sesuai dengan teori pemasaran yaitu: Semakin panjang saluran pemasaran, biaya pemasaran akan semakin besar karena semakin banyak pelaku-pelaku yang ikut serta dalam kegiatan pemasaran yang menyebabkan biaya pemasaran semakin besar, tidak hanya dari semakin banyaknya biaya transportasi saja karena perpindahan produk berkali-kali tetapi juga karena setiap pelaku pasar mengambil keuntungan.

Pola pemasaran konvensional yang dilakukan petani menyebabkan tingkat harga yang diterima oleh petani pada umumnya relatif lebih kecil dibandingkan dengan harga yang diterima oleh pedagang.

Keuntungan yang diterima oleh petani dari kegiatan usahataninya juga relatif kecil, sementara konsumen harus membayar lebih mahal dari harga yang selayaknya ditawarkan, hal ini sebagai akibat dari terjadinya biaya pemasaran yang tinggi dari petani hingga sampai kepada konsumen akhir. Kenyataan lain menunjukkan bahwa disamping lemahnya posisi tawar (Bargaining posistion) petani dalam pemasaran juga semakin maraknya produkproduk pesaing khususnya produk import di pasar yang sama dalam negeri.

Pola saluran pemasaran yang paling efisien adalah pola III. Hal tersebut terlihat dari rantai pemasaran yang lebih pendek, marjin pemasaran yang lebih kecil, dan keuntungan yang diterima petani lebih besar. Pendeknya rantai pemasaran pola III membuat cabai lebih segar sampai ke konsumen karena terjadinya kerusakan semakin kecil.

Beberapa kendala yang dihadapi dalam rantai nilai distribusi Cabai Merah Besar adalah petani berlahan minim banyak terkendala oleh tidak adanya transportasi yang dimiliki sehingga ketergantungan terhadap tengkulak, sulitnya merubah pola pikir masyarakat tentang usaha tani yang maju.

Hal ini dimanfaakan baik oleh para pelaku pasar (mata rantai distribusi) yang lebih menguasai informasi dan selalu mengikuti perkembangan dinamika pasar baik besarnya pasokan maupun meningkatnya permintaan yang setiap saat bergejolak.

Kendala ini dapat teratasi dan membentuk sitem pemasaran yang sempurna maka perlu adanya sistem pemberdayaan masyarakat bukan sematamata sebuah konsep ekonomi, pemberdayaan secara implisit mengandung arti menegakkan demokrasi ekonomi dimana kegiatan ekonomi berlangsung dari rakyat oleh rakyat dan untuk rakyat. Konsep ini menyangkut penguasan teknologi, pemilikan modal, dan akses ke pasar dan kedalam sumber-sumber informasi, serta keterampilan manajemen.

Apabila peran serta masyarakat meningkat efektivitasnya, maka sebenarnya upaya pemberdayaan masyarakat telah dijalankan.

Upaya pemberdayaan masyarakat dapat dilakukan dengan meningkatkan efisiensi dan produktifitas melalui pengembangan 
sumberdaya manusia, penguasaan teknologi dan penguatan kelembagaan serta perbaikan sarana dan prasarana ekonomi dan sosial. Upaya ini memerlukan adanya kerjasama yang sinergis dari berbagai kekuatan pembangunan yang ada. Kebutuhan dukungan dari pemerintah ke sektor ini dengan mengembangkan kebijakan dan pengembangan pemberdayaan masyarakat pengolahan pasca panen, pengendalian penyakit, dan dukungan teknis pada produksi, pengolahan, dan pemasaran (Tuffa, 2017).

\section{SIMPULAN}

Pola distribusi usaha tani yang ada tumbuh secara alami sesuai dengan perkembangan dan kebutuhan pelakunya. Pelaku yang ada dalam pola ini adalah petani, tengkulak, penggumpul, pedagang besar, pengecer, konsumen. Rantai nilai distribusi Cabai Merah Besar Besar dalam pola yang tumbuh secara alami ini, seringkali menjadikan penetapan harga lebih dominan oleh pedagang. Sehingga petani menerima harga sedikit lebih rendah dibandingkan harga pasar.

Beberapa kendala yang dihadapi dalam pendistribusian Cabai Merah Besar adalah sulitnya merubah pola pikir masyarakat tentang usaha tani yang maju. Hal ini dimanfaakan baik oleh para pelaku pasar (rantai nilai distribusi) yang lebih menguasai informasi dan selalu mengikuti perkembangan dinamika pasar baik besarnya pasokan maupun meningkatnya permintaan yang setiap saat bergejolak.

\section{DAFTAR PUSTAKA}

Aciar. 2012. Membuat Rantai Nilai Lebih Berpihak Pada Kaum Miskin. Buku Pegangan Bagi Praktisi Analisis Rantai Nilai. Australian Government. Australian Centre for International Agricultural Research (ACIAR).

Arikunto, Suharsimi. 2002. Prosedur Penelitian Suatu Pendekatan Praktek. Jakarta: PT Rineka Cipta.

Bungin, Burhan. 2013. Metodologi Penelitian Sosial Ekonomi: Format-Format Kuantitatif dan Kualitatif untuk Studi Sosiologi, Kebijakan, Publik, Komunikasi, Manajemen, dan Pemasaran. Kencana Prenada Media Group. Jakarta.
Boediono. 1996. Teori Pertumbuhan Ekonomi. Badan Penerbit Fakultas Pertanian Ekonomi (BPFE) UGM, Yogyakarta.

BPS Semarang. 2016. Kab Semarang Dalam Angka. Badan Pusat Statistik Kab Semarang.

Dinas Pertanian Provinsi Jawa Tengah, 2015. Laporan Tahunan Tahun 2015.

Dinas Pertanian Tanaman Pangan Provinsi Jawa Tengah.

Firdaus, Muhammad. 2009. Manajemen Agribisnis. Jakarta: Bumi Aksara

Husaini, Umar. 1995. Metodologi Penelitian Sosial. Bandung: Bumi Aksara.

Kuncoro, M. 2006. Strategi Bagaimana Meraih Keunggulan Kompetitif. Jakarta: Erlangga.

Mudda, S. K., Giddi, C. B., PVGK, M. 2016. A study on the digitization of supply chains in agriculture - an Indian experience. Journal of Agricultural Informatics 8 (1), 45-55.

Rangkuti F. 2009. Flexible Marketing. Cetakan Kedua. Jakarta: PT. Gramedia Pustaka Utama.

Sukiyono, Ketut. 2005. Factor Penentu Tingkat Efisiensi Teknik Usahatani Cabai Merah Di Kecamatan Sepulu Rejang, Kabupaten Rejang Lebong. Fakultas Pertanian Bengkulu, Bengkulu.

Samadi, B. 2007. Budidaya Cabai Merah Secara Komersial. Yayasan Pustaka

Somashekhar, I. C., Raju, J. K., Hemapatill. 2014. Agriculture Suplly Chain Management: A Scenario in India. Research Journal of Science and Management, 4(7).

Tuffa, C. A., Amentae, T. K., Gebresenbet, G. 2017. Value Chain Analysisi International Journal of Managing Value and Supply of Warqe Food Products in Ethiopia. Chains (IJMVSC), 8(1).

Nusatama. Yogyakarta.

Sudjana. 2003. Metoda Statistika. Bandung: Tarsito.

Moleong J. Lexy. 2002. Metode Penelitian Kualitatif. Bandung: PT Remaja Rosdakarya

Sugiyono. 2011. Metode Penelitian Kuantitatif, Kualitatif, dan R\&D. Bandung: Alfabeta.

Soekartawi. 2010. Agribisnis, Teori dan Aplikasinya. Jakarta: Rajawali Pers. 1995. Analisis Usahatani. Jakarta: Universitas Indonesia. 